Ratri, P. M., \& Pratisti, W. (2019). Teknik modelling dan bimbingan konseling kelompok untuk meningkatkan motivasi belajar pada siswa SMP X Surakarta. Indigenous: Jurnal Ilmiah Psikologi, 4(2), 125-133. https://doi.org/10.23917/indigenous.v4i2.7730.

\title{
Teknik Modelling dan Bimbingan Konseling Kelompok untuk Meningkatkan Motivasi Belajar pada Siswa SMP X Surakarta
}

\author{
Prapti Madyo Ratri ${ }^{1}$, Wiwien Dinar Pratisti ${ }^{2}$ \\ Fakultas Psikologi Universitas Muhammadiyah Surakarta ${ }^{12}$ \\ praptimr@gmail.com¹,wiwien.pratisti@ums.ac.id ${ }^{2}$
}

\begin{abstract}
The main and often conveyed guidance counselimg teacher complaints are the lack of enthusiasm of student in learning and lack of motivation to learn. Effort to overcome the problem of learning motivation have been carried out by showing varied result. This research aims to examine the effect of counseling guidance by using the model on increasing the motivation of junior hight school students learn. The experimental design used was in the form of one group pretest posttest design, while the selection of research subjects was conducted using a scale of learning motivation and the results of the counseling teacher interview. Students who show low learning motivation will be selected as research subjects. Based on the scale that has been disseminated and the results of interviews with selected counseling guidance teachers 8 students. Measuring learning motivation using a scale of learning motivation, interviews and observation. The efectiveness of the infleuence of group counseling guidance was tested using a nonparametric test with wilcoxon technique. The result show a coefficient of $-2,366$ with a significance level of $0.018(p<0.05)$ which can be interpreted that there is an increase in learning motivation after group counseling is given guidance. Thus it can be concluded that group counseling guidance using models can incrase student motivation.
\end{abstract}

Keyword: Motivation to learn; model; group counseling gudance

Abstrak: Keluhan guru bimbingan konseling yang utama dan sering disampaikan adalah kurangnya semangat siswa dalam belajar dan kurang menunjukkan motivasi untuk belajar. Upaya untuk mengatasi permasalahan motivasi belajar telah banyak dilakukan dengan menunjukkan hasil yang bervariasi. Pada penelitian ini bertujuan untuk menguji pengaruh Bimbingan Konseling Kelompok dengan menggunakan model pada peningkatan motivasi belajar siswa Sekolah Menengah Pertama (SMP). Rancangan eksperimen yang digunakan berupa one group pretest-posttest design. Delapan siswa menunjukkan motivasi belajar rendah berdasarkan skala motivasi belajar dipilih menjadi subjek penelitian. Intervensi yang digunakan adalah bimbingan konseling dan bimbingan konseling. Data yang terkumpul dianalisis menggunakan uji nonparametrik dengan teknik wilcoxon. Hasilnya menunjukkan koefisien sebesar-2,366 dengan taraf signifikansi 0,018 ( $p<0,05)$, yang dapat diartikan bahwa nilai post test lebih besar daripada nilai pre-test sehingga dapat dinyatakan bahwa terjadi peningkatan motivasi belajar setelah diberikan bimbingan konseling kelompok. kesimpulannya bahwa bimbingan konseling kelompok dengan menggunakan model dapat meningkatkan motivasi belajar siswa.

Kata Kunci: Motivasi belajar; model; bimbingan konseling kelompok

\section{PENDAHULUAN}

Proses belajar mengajar dilaksanakan oleh guru sebagai tenaga pengajar terkadang masih mengalami beberapa masalah umum, meskipun dalam jenjang sekolah menengah pertama ini setiap mata pelajaran diampu oleh satu guru. SMP X di Surakarta merupakan 
salah satu sekolah pada jenjang pendidikan menengah pertama, yang membuka kelas mulai dari kelas tujuh sampai dengan kelas sembilan, masing-masing tingkatan kelas memiliki kelas program khusus, global, dan regular. Berdasarkan hasil wawancara yang diakukan dengan bapak wali kelas $7 \mathrm{G}$ dan Guru BK, menyampaikan bahwa pada masingmasing kelas memiliki karakteristik siswa yang berbeda-beda. Sebagai salah satu sekolah dijenjang pendidikan menengah pertama, SMP $\mathrm{X}$ di Surakarta mempunyai gambaran yang beragam mengenai kondisi berlangsungnya proses kegiatan belajar mengajar pada tiaptiap tingkatan kelas beserta kendala-kendala yang dihadapi oleh tenaga pengajar/guru dalam menjalin interaksi dengan siswa selama proses belajar mengajar berlangsung.

Hasil wawancara awal dengan wali kelas dan guru mata pelajaran menunjukkan bahwa, mayoritas guru pelajaran mengalami kendala yangumum dihadapi dalam proses pembelajaran di sekolah yang disebutkan antara lain siswa kurang bersemangat dalam menerima pelajaran, siswa kurang termotivasi untuk mengikuti pelajaran, hal tersebut tercermin dalam perilaku siswa yang sering ramai sendiri ketika guru sedang menjelaskan, dan banyaknya siswa yang tidak mau mengerjakan tugas jika tugas yang diberikan tersebut dirasa sulit. Kehidupan akademis semua murid, ada waktunya menghadapi kesalahan, nilai yang buruk, kebosanan, kelelahan, hilangnya kebulatan tekad, dan ujian-ujian yang menakutkan. Adakalanya mereka yang memiliki motivasi tinggi sekalipun menunjukkan kemerosotan, keraguan-raguan, ketakutan, dan kecemasan. Efektivitas pelaksanaan proses belajar mengajar dalam kelas dipengaruhi beberapa faktor, salah satunya adalah faktor internal dari siswa sendiri terkait motivasi belajarnya.

Alderfer (dalam Nashar, 2004) menjelaskan motivasi belajar adalah kecenderungan siswa dalam melakukan kegiatan belajar yang didorong oleh hasrat untuk mencapai prestasi atau hasil belajar sebaik mungkin. McClelland (2005) menambahkan bahwa motivasi belajar pada umumnya dapat mempertinggi prestasi dan memperbaiki sikap siswa terhadap tugas-tugas sekolah, sehingga motivasi dapat membangkitkan rasa puas dan meningkatkan prestasi belajar siswa.

Hasil wawancara subjek, pada dasarnya siswa termotivasi untuk melakukan aktivitas untuk dirinya sendiri karena ingin mendapatkan kesenangan dari pelajaran atau merasa kebutuhannya terpenuhi. Ada juga yang termotivasi melaksanakan belajar dalam rangka memperoleh penghargaan atau menghindari hukuman dari luar dirinya sendiri. Berdasarkan hasil penyebaran angket, dari 25 siswa SMP Muhammadiyah X Surakarta, terdapat 10 siswa yang memiiki motivasi belajar rendah, namun gugur 2 karena ketika proses wawancara dan konseling awal kedua subjek tidak masuk sekolah. Permasalahan terkait kurangnya motivasi belajar, terutama pada siswa kelas 7 SMP X di Surakarta perlu mendapatkan penanganan. Jika permasalahan terus menerus terjadi maka dapat menghambat proses perkembangan kemampuan para siswa di jenjang pendidikan menengah pertama, terutama pada prestasi belajar siswa. Menurut Sadirman (2003) motivasi belajar sangat penting karena motivasi belajar merupakan syarat mutlak dalam proses pencapaian prestasi belajar siswa.

Beberapa cara dapat dilakukan untuk meningkatkan motivasi siswa yaitu dengan teknik modelling. Teknik modelling secara tidak langsung atau symbolic merupakan cara atau prosedur yang dilakukan menggunakan media seperti film, video, dan buku pedoman. Modelling simbolik dilakukan dengan cara mendemonstrasikan perilaku yang dikehendaki atau yang hendak dimiliki siswa melalui media, dalam penelitian ini menggunakan film. Konseling kelompok dengan menggunakan model merupakan teknik konseling yang digunakan untuk mempelajari tingkah laku baru dengan mengamati model dan mempelajari keterampilan yang dimiliki oleh sang model yang berperan sebagai rangsangan bagi pikiranpikiran, sikap-sikap, dan perubahan tingkah laku individu dengan mengamati seorang model dan kemudian diperkuat untuk mencontoh tingkah laku sang model, yang dilakukan secara 
berkelompok Corey (1998).

Layanan bimbingan konseling kelompok merupakan suatu cara memberikan bimbingan kepada individu melalui kegiatan kelompok (Tohirin, 2007). Menurut Sukardi (2008) layanan bimbingan kelompok merupakan layanan bimbingan yang memungkinkan sejumlah peserta didik secara bersama-sama memperoleh berbagai bahan dari narasumber tertentu yang digunakan untuk menunjang kehidupan sehari-hari baik individu maupun sebagai pelajar, anggota keluarga dan masyarakat serta untuk pertimbangan dalam mengambil keputusan. Sedangkan modelling merupakan belajar melalui observasi dengan menambahkan atau mengurangi tingkah laku yang teramati, menggenalisir berbagai pengamatan sekaligus melibatkan kognitif (Komalasari, 2011).

Rosjidan (1998) berpendapat sama bahwa penerapan teknik modelling menunjuk pada proses dimana tingkah laku individu ataupun kelompok bertindak sebagai stimulus yang mempengaruhi pikiran, sikap dan tingkah laku pengamatnya. Komalasari (2011) menambahkan bahwa teknik modelling digunakan dalam layanan konseling kelompok karena teknik modelling dapat menunjukkan terjadinya suatu proses belajar melalui pengamatan terhadap orang lain dan perubahan terjadi melalui pengamatan. Konselor menunjukkan kepada klien tentang perilaku model melalui film. Siswa yang memiliki motivasi belajar rendah akan mampu lebih terarah dalam memperbaiki tingkah laku sesuai dengan model yang diamati berdasarkan model. Sehingga melalui modelling, siswa dapat mengubah tingkah laku yang lama dan memperoleh tingkah laku yang baru dalam masa perkembangan proses belajar.

Penelitian Rahmanto (2011) tentang upaya meningkatkan motivasi belajar melalui layanan penguasaan konten dengan teknik modelling pada siswa SMA NU 05 Brangsong Tahun ajaran 2010/2011 menyatakan bahwa motivasi belajar siswa dapat ditingkatkan melalui layanan penguasaan konten dengan teknik modelling. Hal ini dapat dilihat dari prosentase siswa yang mempunyai motivasi belajar rendah naik sebesar 4,92\% yang sebelumnya memiliki skor $60,53 \%$ menjadi $65,45 \%$. Selain itu dari hasil uji t juga menunjukkan bahwa adanya perubahan prosentase motivasi belajar siswa, peningkatan yang signifikan setelah dilakukan layanan penguasaan konten dengan teknik modelling.

Penelitian lain dilakukan oleh Fauzi (2008) menyatakan bahwa berdasarkan hasil bahwa layanan bimbingan kelompok dengan menggunakan teknik modelling efektif meningkatkan motivasi belajar siswa SMA Unggul Negeri 8 Palembang. Penelitian tersebut didukung dengan hasil penelitian yang dilakukan oleh Laksono (2017), dengan judul "Keefektifan layanan bimbingan kelompok dengan teknik modelling untuk meningkatkan motivasi belajar siswa kelas XI jurusan Tata Boga di SMK Negeri 1 Kersana Brebes tahun ajaran 2016/2017”. Penelitian ini menguji tentang teknik modelling dan bimbingan kelompok yang digunakan untuk meningkatkan motivasi belajar siswa. Hasil penelitian tersebut membuktikan bahwa Motivasi belajar siswa sebelum diberikan layanan bimbingan kelompok teknik modelling masih tergolong kategori rendah. Setelah mendapatkan perlakuan layanan bimbingan kelompok dan teknik modelling, motivasi belajar siswa meningkat.

Hasil penelitian yang dilakukan Yuniarwati (2008) dengan judul meningkatkan motivasi belajar melalui layanan bimbingan kelompok dengan teknik modelling pada siswa kelas XI Aph 1 SMK N I Cepu Semester Gasal Tahun 2017 / 2018 menyatakan bahwa teknik modelling dapat meningkatkan motivasi belajar siswa kelas XI APH 1 SMK Negeri I Cepu semester Gasal Tahun 2017 / 2018.

Cara yang lainnya untuk meningkatkan motivasi belajar siswa adalah dengan bimbingan konseling. Penelitian yang dilakukan oleh Sudarti (2018) peningkatkan motivasi belajar siswa melalui bimbingan kelompok, hasil simpulan menyatakan ada peningkatkan motivasi belajar melalui bimbingan kelompok pada siswa kelas VII. H SMP Negeri 1 Trangkil Pati semester 2 tahun pelajaran $2017 / 2018$, teruji dan terbukti kebenarannya berdasarkan data-data hasil temuan mulai kondisi awal sampai siklus 2 ada 
peningkatan sebesar $27.86 \%$.

Penelitian lain dilakukan oleh Purwanita, Dantes dan Setuti (2013) dengan judul penelitian penerapan bimbingan kelompok untuk meningkatkan motivasi belajar siswa yang mengalami kesulitan belajar di kelas VII C SMP Negeri 3 Singaraja menyatakan dari hasil penelitian, bimbingan kelompok dapat meningkatkan motivasi belajar siswa yang mengalami kesulitan belajar dengan hasil pada awal sebelum diberikan perlakuan, motivasi belajar siswa dalam kategori rendah dengan ratarata persentase yaitu $61,26 \%$. Siswa tersebut kemudian diberikan perlakuan yaitu layanan bimbingan kelompok. Hasil yang diperoleh yaitu dari 9 orang siswa yang diberikan layanan yang mampu mencapai kriteria ketuntasan di atas $65 \%$ adalah 4 orang, sedangkan 5 orang lainnya belum mencapai kriteria ketuntasan di atas 65\%.

Penelitian tersebut diperkuat dengan hasil penelitian Mutammimah (2018) dengan judul peningkatan motivasi belajar melalui bimbingan kelompok dengan media audiovisual pada siswa kelas X MAN 1 Kudus. Kondisi motivasi belajar siswa yang menjadi subjek penelitian sebelum bimbingan kelompok diperoleh hasil yang tergolong kurang, hal tersebut dapat terlihat dari hasil pre-test pemberian skala motivasi belajar sebelum pelaksanaan bimbingan kelompok dengan media audiovisual, berada dalam kategori rendah/kurang. Peningkatan yang dialami setelah mendapat layanan bimbingan kelompok dapat terlihat dari hasil post-test mengalami skor peningkatan, dan berdasarkan hasil observasi peneliti dan kolaborator proses bimbingan kelompok dengan media audiovisual juga ada peningkatan dari Siklus I ke Siklus II menjadi lebih aktif. Hasil dari penelitian tersebut layanan bimbingan kelompok dengan media audiovisual mampu memberikan dampak terhadap peningkatan motivasi belajar Siswa kelas X MAN 1 Kudus.

Berdasarkan hal tersebut, maka peneliti ingin mengetahui bagaimana efektifitas teknik modelling dan bimbingan konseling kelompok untuk meningkatkan motivasi belajar siswa di SMP X Surakarta.

\section{METODE}

Penelitian ini adalah penelitian quasi experiment yang menggunakan one group pretest - post test design (Shadish, Cook \& Campbell, 2002). Variabel bebas dalam penelitian ini berupa bimbingan konseling dengan teknik modelling, sedangkan variabel tergantung berupa motivasi belajar. Pengukuran dilakukan dua kali, di awal/sebelum perlakuan diberikan (pre-test) dan di akhir/sesudah perlakuan (posttest), di awal penelitian dilakukan pengukuran terhadap variabel tergantung pada subjek. Kemudian setelah diberikan perlakuan dilakukan pengukuran kembali terhadap variabel tergantung pada subjek dengan alat ukur yang sama (Seniati \& Setiadi, 2005).

Penelitian ini dilakukan di SMP $\mathrm{X}$ Surakarta, kelas 7. Peneliti menggunakan metode random sampling dalam menentukan subjek dengan menggunakan skala motivasi belajar. Kelompok siswa tersebut diminta untuk menjadi peserta dan terlibat aktif dalam mengikuti suatu pelatihan yang disampaikan

Tabel 1 Data Identitas Subjek Penelitian

\begin{tabular}{cccc}
\hline No & Nama & Usia & Jenis Kelamin \\
\hline 1. & MRP & 13 tahun & Laki-Laki \\
2. & DM & 13 tahun & Perempuan \\
3. & APP & 13 tahun & Laki-Laki \\
4. & NAA & 13 tahun & Perempuan \\
5. & ADPP & 13 tahun & Laki-Laki \\
6. & AEP & 13 tahun & Laki-Laki \\
7. & BR & 13 tahun & Laki-Laki \\
8. & PDL & 13 tahun & Perempuan \\
\hline
\end{tabular}

128 | Teknik Modelling dan... 
Tabel 2. Data Motivasi Belajar Pre-Test dan Post-Test

\begin{tabular}{ccccc}
\hline No & Nama & Pre-Test & Kategori & Post-Test \\
\hline 1. & MRP & 121 & Sedang & 157 \\
2. & DM & 127 & Sedang & 178 \\
3. & APP & 123 & Sedang & 123 \\
4. & NAA & 129 & Sedang & 135 \\
5. & ADPP & 117 & Sedang & 121 \\
6. & AEP & 124 & Sedang & 146 \\
7. & BR & 101 & Sedang & 142 \\
8. & PDL & 127 & Sedang & 168 \\
\hline
\end{tabular}

oleh tim dari peneliti.

Asesmen awal dengan skala motivasi pada 127 siswa, terdapat 25 orang siswa yang menunjukkan skor motivasi belajar rendah, 10 orang di antaranya bersedia menjadi subjek penelitian, namun pada saat pelaksanaan 8 orang siswa yang bersedia untuk menjadi subjek penelitian dan akan mendapatkan intervensi berupa teknik modelling dan bimbingan konseling kelompok .

Subjek berjumlah 8 orang Penelitian ini adalah penelitian kuasi eksperimen dengan memberikan perlakuan kepada sekelompok subjek dan dilakukan pengukuran sebelum dan sesudah perlakukan diberikan. Berdasarkan isian identitas yang dilakukan oleh subjek penelitian, diperoleh 5 orang siswa laki-laki dan 3 orang siswa perempuan yang kesemuanya berusia 13 tahun dan bersekolah di sekolah yang sama. Berikut ini merupakan identifikasi subjek penelitian (tabel 1).

Intervensi yang diberikan berupa pelatihan teknik modelling dan bimbingan konseling kelompok. Treatment dilaksanakan sebanyak 3 kali pertemuan dengan 4 sesi. Pada sesi pertama diberikan pretest untuk mengetahui kondisi awal tingkat motivasi belajar siswa. Pertemuan kedua berlangsung selama 45 menit, pada sesi kedua peneliti menentukan kelompok subjek. Kelompok subjek dipilih berdasarkan hasil skor angket siswa yang didapat dari hasil pretest. Kemudian setelah kelompok ditentukan, peneliti melaksanakan bimbingan kelompok dengan memberikan pemahaman tentang motivasi belajar. Sebelum memberikan materi motivasi belajar, diajukan pertanyaan untuk mengetahui pemahaman siswa tentang motivasi, dilanjutkaan dengan pemberian materi tentang pengertian motivasi, jenis-jenis motivasi, dan fungsi motivasi dalam belajar.

Sesi ketiga berdurasi 120 menit dengan menayangkan video motivasi belajar dengan judul "Sepatu Dahlan". Video tersebut menceritakan tentang seorang anak yang memiliki motivasi dan semangat belajar tinggi, meskipun berasal dari keluarga yang sederhana dan sering di dipandang sebelah mata namun tidak pernah merasa kecil hati dan justru anak tersebut membuktikan bahwa dia memiliki semangat serta motivasi belajar yang tinggi dan mampu berprestasi. Pada sesi ke-4, setelah siswa melihat video tersebut, peneliti meminta kepada siswa untuk mengemukakan pendapatnya mengenai video yang telah dilihat, pembelajaran apa yang bisa diperoleh dari video tersebut. Tujuan bimbingan kelompok dengan menampilkan video yaitu agar siswa dapat melihat, memperhatikan dan meniru perilaku model yang memiliki motivasi belajar baik. Peneliti mengajukan pertanyaan kepada siswa tentang motivasi belajar untuk melihat apakah setelah dilakukan layanan bimbingan kelompok dengan menampilkan video "Sepatu Dahlan" pemahaman siswa mengenai motivasi belajar mengalami peningkatan atau tidak. Dari beberapa pertanyaan yang diberikan peneliti, siswa terlihat lebih antusias menjawab pertanyaan mengenai motivasi belajar dibandingkan sebelum diberikan perlakuan dengan teknik modelling dan bimbingan konseling. Selain memberikan pertanyaan secara lisan kepada siswa, pada sesi akhir pertemuan ke-empat peneliti melakukan posttest untuk melihat pemahaman siswa tantang motivasi 
Tabel 3 Data deskriptif pre-test dan post-test

\begin{tabular}{ccccc}
\hline $\mathbf{N}$ & Mean & Std. Dev & Min & Max \\
\hline 8 & 120,25 & 8,664 & 101 & 120 \\
8 & 146,25 & 20,422 & 121 & 178 \\
\hline
\end{tabular}

belajar.

Pengukuran motivasi belajar siswa menggunakan skala motivasi belajar yang terdiri atas 50 aitem berdasarkan aspek motivasi belajar menurut Suryabrata (2006) yaitu adanya sifat ingin tahu, adanya sifat yang kreatif dan keinginan untuk maju, adanya keinginan untuk mendaoatkan simpati dari orang lain, guru dan teman-temannya, adanya keinginan untuk memperbaiki kegagalan, adanya keinginan untuk mendapatkan rasa aman bila menguasai pelajaran dan adanya penghargaan. Skala yang digunakan dalam penelitian ini merupakan hasil adopsi skala motivasi belajar dalam penelitian Desitasari (2016). Skala yang digunakan Desitasari (2016) memiliki nilai validitas bergerak dari 0,75 sampai 0,91 , sedangkan nilai reliabilitas yaitu 0,914 .

Teknik analisis data yang digunakan untuk menguji hipotesis adalah statistik non parametrik dengan menggunakan rumus Wilcoxon match pairs, untuk mengetahui perbedaan signifikan pre test dan post test dengan jumlah sampel kurang dari 25. Perhitungan dalam uji wilcoxon untuk sampel dibawah 25 adalah dengan membandingkan tabel perhitungan yang ada (Sugiyono, 2005).

\section{HASIL DAN PEMBAHASAN}

Hasil skoring data skala motivasi belajar dibuat kategorisasi. Penelitian ini menggunakan 5 kategori jawaban, yaitu sangat rendah (SR), rendah $(\mathrm{R})$, sedang $(\mathrm{S})$, tinggi $(\mathrm{T})$, dan sangat tinggi (ST). Skor mentah digunakan untuk menguji hipotesis secara statistik, dan kategorisasi digunakan untuk melihat perbedaan secara kualitatif. Perbandingan skor pre-test dan posttest dapat dilihat pada tabel 2 . Analisis data yang digunakan oleh peneliti dengan menggunakan uji non-parametric wilcoxon.

Tabel 3 dapat diketahui bahwa subjek berjumlah 8 orang. Selain itu, diperoleh hasil mean (rata-rata) pre-test skala motivasi belajar sebesar 120.25, sedangkan hasil post-test skala motivasi belajar sebesar 146.25. Berdasarkan hasil tersebut dapat disimpulkan bahwa mean pre-test dan post-test mengalami perubahan yakni sebesar 26. Selanjutnya, skor minimal subjek pada skala pre-test sebesar 101 dan skor maksimal sebesar 129, sedangkan untuk skala post-test skor minimal sebesar 121 dan skor maksimal sebesar 178 .

Dari hasil tabel 4 dapat diketahui bahwa sejumlah 7 peserta yang mengalami peningkatan skor motivasi belajar yang dilihat pada baris positive ranks, dan sejumlah 1 peserta memperoleh skor tetap dilihat dari baris Ties menunjukkan 1 peserta yang mengalami kesamaan mean antara pre-test dan post-test.

Selanjutnya, berdasarkan analisis uji nonparametric wilcoxon didapat nilai koefisien sebesar -2.366, dengan Sig 2-tailed sebesar $0,018(\mathrm{p}<0,05)$, hal ini menunjukkan bahwa ada perbedaan yang signifikan pada motivasi belajar pre-test (sebelum mengikuti intervensi) dengan post-test (setelah mengikuti intervensi). Hasil tersebut menunjukkan bahwa rerata post-test lebih tinggi dibandingkan dengan rerata pretest, yang dapat diartikan bahwa telah terjadi peningkatan skor motivasi belajar. Berdasarkan penjelasan di atas maka dapat disimpulkan

Tabel 4. Tabel Peningkatan Skor Pre-Post Test

\begin{tabular}{lccc}
\hline & N & Mean Rank & Sum of Ranks \\
\hline Negative Ranks & $0(\mathrm{a})$ & 0,00 & 0,00 \\
Positive Ranks & $7(\mathrm{~b})$ & 4,00 & 28,00 \\
Ties & $1(\mathrm{c})$ & & \\
Total & 8 & & \\
\hline
\end{tabular}

130 | Teknik Modelling dan... 
Tabel 5. Hasil Signifikansi Uji Wilcoxon

\begin{tabular}{ccc}
\hline & Hasil Post-Pre-test & Makna \\
\hline Nilai Z & $-2,366$ & ada pengaruh \\
signifikansi & 0,018 & \\
\hline
\end{tabular}

bahwa secara kuantitatif intervensi tentang teknik modelling dan bimbingan konseling efektif untuk meningkatkan motivasi belajar.

Hasil kualitatif didapatkan dari wawancara yang dilakukan kepada beberapa guru mengungkapkan bahwa siswa memiliki minat dalam mengikuti pembelajaran di kelas, siswa-siswi lebih rajin masuk kelas untuk mengikuti proses belajar mengajar dan ketika guru memberikan tugas, siswa dengan cepat untuk mengerjakannya.

Menurut penuturan siswa setelah diberikannya intervensi teknik modelling dan bimbingan kelompok siswa menjadi lebih bersemangat dalam mengikuti pemberalajaran di kelas, memiliki contoh atau teladan yang mampu dicontoh dalam kesehariannya terutama dalam hal belajar dan siswa menjadi lebih disiplin dalam belajar.

Penelitian ini bertujuan untuk mengetahui pengaruh teknik modelling dan bimbingan konseling kelompok terhadap peningkatan motivasi belajar siswa SMP. Berdasarkan analisis data yang telah dilakukan secara kuantitatif didapatkan hasil bahwa terdapat perbedaan tingkat motivasi belajar sebelum dan setelah dilakukan intervensi. Hal tersebut dibuktikan dari hasil analisis pada uji Wilcoxon didapatkan hasil mean (ratarata) pre-test skala motivasi belajar sebesar 120.25, sedangkan hasil post-test skala motivasi belajar sebesar 146.25 dengan nilai koefisien sebesar -2.366, dengan Sig 2-tailed sebesar 0,018 ( $\mathrm{p}<0,05)$. Maka keputusannya adalah Ho ditolak dan $\mathrm{Ha}$ diterima, hal ini berarti teknik modelling dan bimbingan konseling kelompok efektif untuk meningkatkan motivasi belajar siswa SMP. Hal ini sesuai dengan hasil penelitian yang dilakukan oleh Rumiani, Suarni, \& Putri (2014) menyatakan bahwa hasil penelitian dapat disimpulkan bahwa pemberian konseling behavioral teknik modelling melalui konseling kelompok terbukti meningkatkan motivasi belajar siswa kelas VIII 6 SMP Negeri 2 Singaraja.

Hasil intervensi menunjukkan bahwa peningkatan motivasi belajar siswa bervariasi. Peningkatan motivasi belajar yang dicapai siswa disebabkan karena keantusiasan siswa mengikuti konseling kelompok untuk dapat meningkatkan motivasi belajarnya. Siswa juga memperoleh pemahaman dan pengalaman melalui model yang ditampilkan. Menurut Soekaji (2003) ada beberapa efek meneladani seorang model baik langsung maupun tidak langsung yaitu belajar hal baru melalui pengamatan, pelepasan perilaku, memahami perilaku dan mempermudah timbulnya perilaku.

Gunarsa (1996) yang menyatakan bahwa efek dari meneledani meliputi pengambilan respon atau keterampilan baru, hilangnya respon takut setelah melihat tokoh, melalui pengamatan terhadap tokoh seseorang terdorong untuk melakukan seseuatu yang mungkin sudah diketahui atau dipelajari dan tidak ada hambatan. Selain itu konseling kelompok yang diberikan benar-benar membuat siswa menjadi lebih memahami tujuan dan makna dari konseling agar nantinya apabila siswa tersebut mengalami permasalahan, siswa bisa datang kepada guru Bimbingan Konseling untuk mengutarakan permasalahannya. Berdasarkan hasil yang dicapai tersebut, dapat disimpulkan bahwa pemberian teknik modelling dan bimbingan konseling kelompok mampu meningkatkan Motivasi Belajar siswa SMP X Surakarta.

\section{SIMPULAN}

Berdasarkan analisis yang telah dilakukan, dapat disimpulkan bahwa teknik modelling dan bimbingan konseling kelompok efektif dapat meningkatkan motivasi belajar siswa SMP dengan nilai koefisien sebesar -2.366, dengan Sig 2-tailed sebesar 0,018 
$(\mathrm{p}<0,05)$. Tingkat motivasi belajar siswa sebelum diberikan intervensi termasuk dalam kategori sedang, sedangkan setelah diberikan intervensi tingkat motivasi belajar siswa dalam kategori tinggi dan sangat tinggi.

Berdasarkan hasil observasi yang dilakukan dengan teknik check list, dapat diambil sebuah kesimpulan bahwa perilaku motivasi belajar rendah siswa-siswi setelah dilakukan intervensi teknik modelling dan bimbingan konseling kelompok terdapat 8 perilaku yang mengalami penurunan inetnsitas, dan 2 perilaku dengan intensitas yang relatif tetap. Sedangkan berdasarkan analisis kualitatif diperoleh bahwa siswa mendapatkan beberapa manfaat selama mengikuti pelatihan teknik modelling dan bimbingan konseling kelompok, seperti lebih semangat sekolah, memiliki teladan dalam menggapai cita-cita, tidak mudah putus asa dan lebih fokus pada hal yang sedang dikerjakan.

Saran kepada sekolah untuk mempelajari intervensi sehingga dapat diterapkan ketika pembelajaran dan meningkatkan perannya, bukan sekedar menjadi pengajar namun juga sebagai pendamping siswa saat mengahadapi kesulitan khususnya terkait aktivitas sekolah sehingga siswa mendapatkan dukungan yang cukup di sekolahan. Saran kepada siswa untuk mempertahankan motivasi belajarnya agar lebih bersemangat dalam mengikuti pembelajaran dan apabila siswa mengalami situasi motivasi belajar mulai turun maka siswa perlu menyusun target pembelajaran serta mengingat model yang diberikan ketika proses intervensi.

\section{DAFTAR PUSTAKA}

Desitasari, N. (2016). Hubungan antara dukungan sosial keluarga dengan motivasi belajar siswa SMP. Naskah Publikasi Skripsi. Fakultas Psikologi UMS

Corey, G (1998). Teori dan praktet konseling \& psikoterapi. Bandung : PT Reflika Aditama

Fauzi, T. (2008). Efektivitas layanan bimbingan kelompok dengan teknik modelling dalam meningkatkan motivasi belajar siswa SMA Negeri 8 Palembang. Jaeducation. 1(1), 1-6.

Gunarsa, S.D. (1996). Konseling dan psikoterapi. Jakarta : Gunung Mulia

Komalasari,K. (2011). Pembelajaran kontekstual. Konsep dan aplikasi. Bandung: PT. Refika Aditama

Laksono, A.P. (2017). Keefektifan layanan bimbingan kelompok dengan teknik modelling untuk meningkatkan motivasi belajar siswa kelas XI jurusan tata boga di SMK Negeri 1 Kersana Brebes Tahun Ajaran 2016/2017. Unpublished minor thesis. Universitas Negeri Semarang.

Mc Clelland, (2005). Studies in motivation. New York: Appleton Craft.

Mutammimah, E. (2018). Peningkatan motivasi belajar melalui bimbingan kelompok dengan media audiovisual pada siswa kelas X MAN 1 Kudus. Konseling Edukasi: Journal of Guidance and Counseling. 2(1). Retrieved from http://journal.stainkudus.ac.id/index. php/Konseling_Edukasi/article/download/3932/pdf

Nashar. (2004). Peranan motivasi dan kemampuan awal dalam kegiatan pembelajaran. Jakarta: Delia Press.

Purwanita, N.W.H., Dantes, N., \& Setuti, N. M. (2013). Penerapan bimbingan kelompok untuk meningkatkan motivasi belajar di kelas VII C SMP Negeri 3 Singaraja. Jurnal Ilmiah Bimbingan Konseling. 1(1). https://ejournal.undiksha.ac.id/index.php/JJBK/article/view/ 908/778

Rahmanto, B. D. (2011). Upaya meningkatkan motivasi belajar melalui layanan penguasaan kont en dengan teknik modelling pada siswa SMA NU 05 Brangsong tahun ajaran 2010/2011. Skripsi. Universitas Negeri Semarang. 
Rosjidan, M.A. (1998). Pengantar konseling . Program Pasca Sarjana Universitas Negeri Malang. Tesis

Rumiani, N.W., Suarni, N.K., \& Putri, D.A.W.M. (2014). Penerapan konseling behavioral teknik modelling melalui konseling kelompok untuk meningkatkan motivasi belajar siswa kelas VIII 6 SMPN 2 Singaraja Tahun Pelajaran 2013/2014. Ejournal Undiksha Jurusan Bimbingan Konseling, 2(1). https://ejournal.undiksha.ac.id/index.php/JJBK/article/ view/3656/2944

Santrock, J. W. (2001). Lifespan development. McGraw-Hill: Boston

Sardiman (2003). Interaksi dan motivasi belajar mengajar. Jakarta: PT. Raja Grafindo Persada

Slameto. (2003). Belajar dan faktor-faktor yang mempengaruhinya. Jakarta: Rineka Cipta.

Soekaji, S. (2003). Modifikasi perilaku penerapan sehari-hari dan penerapan profesional. Yogyakarta: LIBERTY

Sudarti, K. (2018). Peningkatkan motivasi belajar siswa melalui bimbingan kelompok. Jurnal Prakarsa Paedagogia, 1(1), 14-23.

Sukardi (2008). Metodologi penelitian pendidikan, kompetensi, dan prakteknya. Jakarta : PT. Bumi Aksara

Suryabrata, S. (2011). Psikologi pendidikan. Jakarta: PT. Raja Grafindo Persada

Tohirin (2007). Bimbingan dan konseling di Sekolah dan Madrasah (Berbasis Integrasi). Jakarta : PT. Raja Grafindo Persada.

Yuniarwati, C.T,. (2008). Meningkatkan motivasi belajar melalui layanan bimbingan kelompok dengan teknik modelling pada siswa Kelas XI Aph 1 SMK N I Cepu semester gasal tahun 2017 / 2018. Empati, 8(1), 1-11.

Yusuf, S. (2009). Program bimbingan dan konseling di sekolah. Bandung: Rizqi Press. 